OPEN ACCESS

ISSN 2580-7730 (online)

Edited by:

Andika Aliviameita

Reviewed by: Mely Purnadianti

${ }^{*}$ Correspondence:

Andreas Putro Ragil Santoso andreasprs87@gmail.com

Received: 1 Oktober 2020 Accepted: 30 November 2020 Published: 31 Desember 2020

Citation:

Santoso APR, Masruroh N Amalia IN, Santy WH (2020)

Relationship between Blood

Pressure and Urine Protein in

Preeclampsia at Prima Husada Hospital Sidoarjo

Medicra (Journal of Medical Laboratory Science/Technology).

10.21070/medicra.v3i2.1081

\section{Relationship between Blood Pressure and Urine Protein in Preeclampsia at Prima Husada Hospital Sidoarjo}

\section{Hubungan Tekanan Darah Dengan Protein Urine Pada Kejadian Preeklamsia Di RSU Prima Husada Sidoarjo}

\author{
Andreas Putro Ragil Santoso ${ }^{1 *}$, Nur Masruroh ${ }^{2}$, Ikke Nanda Amalia ${ }^{1}$, Wesiana Heris Santy ${ }^{3}$ \\ ${ }^{1}$ D-IV Analis Kesehatan, Fakultas Kesehatan, Universitas Nahdlatul Ulama, Surabaya Jawa Timur, Indonesia \\ ${ }^{2}$ D-III Keperawatan, Fakultas Keperawatan dan Kebidanan, Universitas Nahdlatul Ulama Surabaya, Jawa Timur, Indonesia \\ ${ }^{3} S 1$ Keperawatan, Fakultas Keperawatan dan Kebidanan, Universitas Nahdlatul Ulama Surabaya, Jawa Timur, Indonesia
}

The problems related to pregnancy and childbirth including maternal and infant mortality rates can't be removed from another causative factors that arise, one of the second cause from maternal mortality rates is preeclampsia, which is a specific disorder of hypertension caused by pregnancy at gestational age of more than 20 weeks with proteinuria and rarely occurs before 20 weeks gestational except if any kidney or trophoblastic disease. Hypertension and proteinuria to be a symptoms that often appears in preeclampsia diagnose. The relationship between of risk factor occur preeclampsia, that is blood pressure and protein urine which is the important indicator for enforcement of preeclampsia. The purpose of researchis analyze the relationship between of blood pressure and protein urine levels on the incidence of preeclampsia. The type of this research is analytic observational. Sample of this research is pregnant mother with preeclampsia in RSU Prima Husada Sidoarjo. The results use the Correlation Pearson test showed that $p$ value for the systolic blood pressure is 0.791 and the diastolic blood pressure is 0.268 , this is shows that blood pressure isn't related with protein urine.

Keywords: blood pressure, preeclampsia, urine protein

Masalah terkait kehamilan dan persalinan termasuk Angka Kematian Ibu tidak dapat lepas dari berbagai faktor penyebab yang timbul, salah satu penyebab ke-2 dari kematian ibu di Indonesia ialah preeklamsia, yang merupakan gangguan spesifik hipertensi yang disebabkan oleh kehamilan di usia kehamilan $>20$ minggu disertai proteinuria dan jarang timbul sebelum usia kehamilan 20 minggu, kecuali jika terdapat penyakit ginjal ataupun trofoblastik. Hipertensi dan proteinuria menjadi gejala yang sering muncul dalam diagnosis preeklamsia. Hubungan diantara faktor risiko terjadinya preeklamsi, yakni tekanan darah dan protein urin merupakan indikator penting untuk penegakan kasus preeklamsia. Tujuan dari penelitian ini adalah untuk menganalisis hubungan antara tekanan darah dan kadar protein urin 
pada kejadian preeklamsia. Jenis penelitian ini adalah analitik observasional. Sampel pada penelitian ini merupakan ibu hamil dengan preeklamsia di RSU Prima Husada Sidoarjo. Hasil analisis diuji menggunakan Korelasi Pearson yang menunjukkan bahwa $\mathrm{p}$ value untuk tekanan darah sistolik terhadap protein urin sebesar 0,791 dan tekanan darah diastolik sebesar 0,268. Hal ini menunjukkan bahwa tekanan darah tidak berhubungan dengan protein urin.

Kata Kunci: preeklamsia, protein urin, tekanan darah 


\section{PENDAHULUAN}

Indikator penilaian suatu pelayanan kesehatan di seluruh dunia, dapat diukur melalui angka kematian ibu dan bayi Mutiara et al. (2018). Angka kematian ibu merupakan jumlah wanita yang meninggal terkait dengan gangguan ataupun penanganan kehamilan tanpa memperhitungkan lama kehamilan per 100.000 kelahiran hidup Yanti (2020). Pada tahun 2015, sekitar 830 kematian ibu di dunia yang dilaporkan meninggal akibat penyakit atau komplikasi terkait kehamilan maupun persalinan Mutiara et al. (2018). Sementara itu, menurut hasil SUPAS pada tahun 2015, angka kematian ibu dilaporkan mengalami penurunan sekitar 305 kasus per 100.000 kelahiran hidup Kemenkes RI (2019). Walaupun angka kematian ibu di Indonesia telah mengalami penurunan di tahun 2015, masalah yang berhubungan dengan kehamilan dan persalinan terutama angka kematian ibu tidak terlepas dari berbagai faktor penyebab yang timbul. Salah satu penyebab ke-2 dari kematian ibu di Indonesia ialah preeklamsia, yang mencapai angka sebesar 24\% Saraswati and Mardiana (2016).

Preeklamsia merupakan gangguan spesifik hipertensi yang disebabkan oleh kehamilan, pada usia kehamilan $>20$ minggu disertai proteinuria dan jarang timbul sebelum 20 minggu usia kehamilan kecuali jika terdapat penyakit ginjal ataupun trofoblastik Setyawan et al. (2019). Kedua gejala dari preeklamsia, yakni hipertensi yang disertai proteinuria ini merupakan gejala yang paling penting dalam penegakan kasus diagnosis preeklamsi Fadhila et al. (2018).

Sekitar 5-15\% penyulit kehamilan ialah hipertensi dan merupakan salah satu dari tiga penyebab yang tertinggi pada mortalitas dan morbiditas ibu bersalin. Hipertensi pada kehamilan terjadi apabila tekanan darah $\geq 140 / 90 \mathrm{mmHg}$ setelah usia kehamilan 20 minggu Ningrum and Nurhoeriyah (2015). Hipertensi mampu menjadi penyebab dari penyakit ginjal kronik dan dapat pula dikaitkan dengan memburuknya fungsi ginjal Sardi and Pusparini (2019). Gejala kedua dari preeklamsia yakni proteinuria Fadhila et al. (2018). Proteinuria merupakan sebuah keadaan yang mana terdapat komponen protein dalam urin Sardi and Pusparini (2019). Sebanyak $\geq 300 \mathrm{mg} / 24$ jam atau urin dipstick $\geq+1$ Fadhila et al. (2018). Pemeriksaan protein urin merupakan salah satu jenis pemeriksaan laboratorium untuk mengetahui fungsi ginjal selama masa kehamilan dan mengidentifikasikan adanya preeklamsia ringan maupun berat yang dapat mengarah ke keadaan eklamsia. Deteksi proteinuria sangat penting dalam diagnosis dan penanganan hipertensi dalam kehamilan. Proteinuria menjadi gejala yang terakhir timbul pada pasien preeklamsia. Namun demikian, eklamsia dapat terjadi tanpa proteinuria. Proteinuria pada preeklamsia merupakan indikator adanya bahaya pada janin, berat badan lahir rendah dan meningkatnya risiko kematian perinatal Setyawan et al. (2019).

Untuk mendukung pernyataan di atas, beberapa penelitian mengenai tekanan darah, pemeriksaan fungsi ginjal dan gambaran kadar protein pada kejadian preeklamsia telah dilakukan. Penelitian mengenai adanya hubungan antara riwayat penyakit hipertensi dengan kejadian preeklamsia pada ibu bersalin oleh Ningrum and Noerhiyah (2015) yang dibuktikan sebanyak $67,4 \%$ responden dengan riwayat hipertensi mengalami preeklamsia. Penelitian selanjutnya dilakukan oleh Setyawan et al. (2019). yang menunjukkan bahwa terdapat berbagai macam variasi gambaran kadar protein urin berdasarkan distribusi tekanan darah pasien. Penelitian yang dilakukan oleh Jumaah (2012) juga mendukung pernyataan bahwa preeklamsi akan berpengaruh terhadap fungsi ginjal yang ditunjukkan melalui meningkatkan kadar kreatinin dan urea.

Berdasarkan latar belakang di atas, penelitian mengenai hubungan antara tekanan darah dengan protein urin pada kejadian preeklamsia perlu untuk dianalisis. Oleh karena itu, penelitian ini dilakukan untuk menganalisis keterkaitan antara tekanan darah dan protein urin sebagai deteksi faktor risiko preeklamsia, sebagai upaya pencegahan terjadinya preeklamsia di RSU Prima Husada Sidoarjo.

\section{METODE}

Desain dalam penelitian ini adalah penelitian analitik observasional. Sampel penelitian yakni ibu hamil dengan preeklamsia di RSU Prima Husada Sidoarjo yang memiliki data rekam medik yang diperiksa dalam suatu waktu tertentu. Data yang dikumpulkan merupakan data primer dari hasil pengukuran tekanan darah dan protein urin. Selanjutnya, data primer tekanan darah dan protein urin tersebut diolah dan dianalisis datanya menggunakan aplikasi IBM SPSS, menggunakan uji statistik Korelasi Pearson, apabila didapatkan hasil bermakna (nilai $\mathrm{p}<$ 0,05), maka variabel tekanan darah, baik sistolik maupun diastolik berhubungan dengan protein urin pada kejadian preeklamsia.

\section{HASIL DAN PEMBAHASAN}

Berdasarkan penelitian yang telah dilakukan, berikut merupakan rerata karakteristik responden penelititan di RSU Prima Husada Sidoarjo disajikan pada Tabel 1. Sedangkan Ringkasan hasil uji Korelasi Pearson yang disajikan pada Tabel 2.

Hasil uji statistik Korelasi Pearson menunjukkan bahwa tekanan darah tidak berhubungan dengan protein urin. Hal ini dibuktikan melalui nilai signifikansi dari Tekanan Darah Sistolik (TDS) terhadap protein urin menunjukkan 0,791>0,05, dan nilai signifikansi dari Tekanan Darah Diastolik (TDD) terhadap protein urin menunjukkan $0,268>0,05$. Pada koefisien korelasi (r) Tekanan Darah Sistolik (TDS) terhadap protein urin menunjukkan angka sebesar 0,051 dan koefisien korelasi (r) Tekanan Darah Diastolik (TDD) terhadap protein urin menunjukkan angka sebesar 0,209. Hal ini menunjukkan bahwa koefisien korelasi pada masing-masing tekanan darah terhadap protein urin tersebut memiliki korelasi yang sangat lemah. 
Usia untuk hamil yang dianjurkan untuk ibu berkisar antara 20-35 tahun, karena usia di bawah 20 tahun dan di atas 35 tahun merupakan kehamilan dengan risiko yang cukup tinggi Fadhila et al. (2018). Pada penelitian ini, didapatkan hasil bahwa range usia ibu hamil preeklamsi di RSU Prima Husada Sidoarjo berkisar antara usia 21-39 tahun. Pada penelitian ini, terdapat usia ibu hamil dengan risiko cukup tinggi, yakni usia ibu hamil di atas 35 tahun terdapat 8 orang. Walau hal ini tidak sesuai dengan pernyataan di atas, namun pada penelitian Fadhila et al. (2018) didapatkan rerata usia ibu hamil berkisar antara 30,03 $\pm 6,81$ tahun.

Pada penelitian ini, usia kehamilan responden berkisar antara 28-37 minggu. Hal ini didukung oleh penelitian Santoso dan Laila (2019) yang menyebutkan bahwa pada kejadian preeklamsia ditemukan di usia kehamilan 34 minggu. Hal ini sejalan dengan Hipertensi yang diikuti dengan proteinuria pada preeklamsi terjadi pada usia kehamilan 20 minggu Fadhila et al. (2018). Pada penelitian ini, usia kehamilan responden berkisar antara 28-37 minggu. Hal ini juga didukung oleh penelitian Santoso and Laila (2019) yang menyebutkan bahwa pada kejadian preeklamsia ditemukan di usia kehamilan 34 minggu.

Preeklamsia merupakan kumpulan dari gejala yang timbul pada ibu hamil, bersalin maupun dalam masa nifas yang terdiri dari beberapa faktor gejala yakni hipertensi, proteinuria, oedema yang terkadang disertai konvulsi sampai koma. Seperti telah disebutkan sebelumnya, bahwa preeklamsi memiliki faktor risiko hipertensi sistolik/diastolik yakni sebesar >140 mmHg Mutiara et al. (2018). Selain itu, sumber lain juga menyebutkan bahwa terjadinya hipertensi mampu menjadi faktor pemburuk dari fungsi ginjal. Tekanan darah yang tinggi dapat merusak pembuluh kapiler dalam glomerulus hingga menyebabkan gagal ginjal Surya et al. (2018). Berdasarkan hasil penelitian ini, batas minimum tekanan darah sistolik dan diastolik ibu hamil preeklamsia yang diperiksa ialah $110 \mathrm{mmhg}$ dan $70 \mathrm{mmhg}$, sedangkan batas maksimum dari tekanan darah sistole dan diastole ibu hamil preeklamsia yang diperiksa ialah $170 \mathrm{mmhg}$ dan 100 mmhg.

Proteinuria merupakan protein yang disekresi melalui urin > 30-150 mg per hari, yang juga menjadi penanda terjadinya gangguan pada ginjal. Jumlah protein yang abnormal merupakan tanda awal dari penyakit ginjal maupun penyakit sintetik yang signifikan. Proteinuria dapat bersifat

TABEL 1 / Rerata Karakteristik Responden Penelitian di RSU Prima Husada Sidoarjo

\begin{tabular}{lll} 
Parameter & Batas Bawah & Batas Atas \\
Usia lbu (Tahun) & 21 & 39 \\
Usia Kehamilan (Minggu) & 28 & 37 \\
Tekanan Darah Sistole & 110 & 170 \\
Tekanan Darah Diastole & 70 & 100 \\
Protein Urin & Negatif & +3 \\
\hline
\end{tabular}

sementara, statis maupun persisten Santoso and Laila (2019). Hasil penelitian rata-rata protein urin ibu preeklamsia yang diperiksa menggunakan reagent dipstick dalam penelitian ini adalah positif +1 dengan persentase sebesar $73.3 \%$, positif +3 sebesar $6.7 \%$, negatif sebesar $20 \%$. Hasil ini sejalan dengan teori yang menyebutkan bahwa pada ibu hamil dengan preeklamsia akan mengalami peningkatan protein yang disebabkan oleh resistensi pembuluh darah yang diperbaiki. Aliran darah renal dan angka filtrasi glomerulus (GFR) pada pasien preeklamsia lebih rendah dibanding dengan pasien kehamilan normal pada usia kehamilan yang sama. Pada penurunan aliran darah renal yang diakibatkan oleh konstriksi di pembuluh darah afferent dapat mengakibatkan kerusakan suatu membran glomerulus sehingga dapat meningkatkan permeabilitas pada protein yang berakibat proteinuria Mutiara et al. (2018).

Berdasarkan hasil penelitian yang dianalisis menggunakan uji statistik Korelasi Pearson pada variabel tekanan darah sistolik dengan protein urin menunjukan nilai signifikansi $\mathrm{p}$ sebesar 0,791 yang menunjukkan bahwa tekanan darah sistolik tidak berhubungan dengan protein urin. Hasil ini juga hampir sama pada tekanan darah diastolik ibu hamil preeklamsia yakni memiliki nilai signifikansi p sebesar 0,268 . Ini juga menunjukkan bahwa tekanan darah diastolik tidak berhubungan dengan protein urin. Hasil penelitian ini sejalan dengan penelitian Fadhila et al. (2018) yang menyatakan bahwa tidak terdapat hubungan yang bermakna antara tekanan darah dengan fungsi ginjal. Tidak didapatkan hubungan bermakna dalam penelitian ini diperkirakan karena banyaknya usia kehamilan ibu di atas 34 minggu. Derajat keparahan preeklamsi pada preeklamsi onset lambat biasanya lebih rendah dibandingkan dengan preeklamsi onset cepat sehingga kerusakan organ yang terjadi masih tergolong minimal.

\section{KESIMPULAN}

Berdasarkan hasil penelitian yang telah dilakukan, maka simpulan dalam penelitian ini menunjukkan bahwa tekanan darah tidak berhubungan dengan protein urin pada kejadian preeklamsia. Hal ini ditunjukkan melalui nilai signifikansi $p$ value $>0,05$.

TABEL 2 / Hasil Uji Statistik Korelasi Pearson

\begin{tabular}{cllll} 
& \multicolumn{2}{l}{ Tekanan Darah Sistolik } & \multicolumn{2}{l}{ Tekanan Darah Diastolik } \\
& $r$ & $p$ value & $r$ & $p$ value \\
Protein Urin & 0,051 & 0,791 & 0,209 & 0,268
\end{tabular}




\section{KONTRIBUSI PENULIS}

Penulis pertama berperan dalam membuat gambaran serta desain penelitian, sedangkan penulis lainnya berperan dalam melakukan pengumpulan data penelitian.

\section{PENDANAAN}

Penelitian ini menggunakan dana dari institusi Universitas Nahdlatul Ulama Surabaya.

\section{REFERENSI}

Fadhila, I., Herman, R. B. \& Yusrawati, (2018). Hubungan Antara Tekanan Darah dan Fungsi Ginjal Pada Preeklamsi di RSUP DR. M. Djamil. Jurnal Kesehatan Andalas, 7(1), 59-64. doi: 10.25077/jka.v7i1.780

Jumaah, I. A. M. (2012). Estimation of uric acid, urea, creatinine and creatinine clearance in the serum of preeclamptic women. Kerbala Journal of Pharmaceutical Sciences, 4(4), 183-189. Retrieved from https://kphrs.uokerbala.edu.iq/pdf_71088_3035ed76b403752dddb44670ac 597626.html

Kementerian Kesehatan Republik Indonesia. (2019). Profil Kesehatan Indonesia, Jakarta: Kementerian Kesehatan Republik Indonesia.

Mutiara, B., Amirus, K., Aryastuti, N., Wulandari, R., Sudirahayu, I. (2018). Analisis Faktor Risiko Yang Mempengaruhi Tekanan Darah dan Protein Urine Pada Ibu Dengan Preeklamsia di RSUD DR. H. Abdul Moeloek Provinsi Lampung 2017. Jurnal Kesmas Khatulistiwa, 5(2), 48-55. doi: 10.29406/jkmk.v5i2.1567

Ningrum, E. W., \& Nurhoeriyah. (2015). Hubungan Antara Riwayat Hipertensi dengan Kejadian Preeklamsia Pada Ibu Bersalin di RSUD Prof. Dr. Margono Soekardjo Purwokerto. Viva Medika, 8(2), 18-29. doi: 10.35960/VM.V9I2.289

Santoso, A. P. R. \& Laila, M. (2019). Hubungan Leukosit dengan Protein Urin Pada Ibu Hamil Trimester III di Puskesmas Klampis Bangkalan Madura. Medical Technology and Public Health Journal, 3(2), 101-106. doi: 10.33086/mtphj.v3i2.1206

Saraswati, N. \& Mardiana. (2016). Faktor Risiko Yang Berhubungan Dengan Kejadian Preeklampsia Pada Ibu Hamil (Studi Kasus di RSUD Kabupaten Brebes Tahun 2014). Unnes Journal of Public Health, 5(2), 90-99. doi: 10.15294/ujph.v5i2.10106

Sardi, K. P., \& Pusparini. (2019). Hubungan Antara Hipertensi dengan Albuminuria Pada Usia 40-70 Tahun. Jurnal Biomedika dan Kesehatan, 2(1), 3-9. doi: 10.18051/JBiomedKes.2019.v2.3-9

Setyawan, J. F. D., Wiryanthini, I. A. D. \& Tianing, N. W. (2019). Gambaran Kadar Protein Urine Pada Ibu Hamil Preeklampsia dan Eklampsia di RSUP Sanglah Denpasar Tahun 2017. Jurnal Medika Udayana, 8(12), 1-5. Retrieved https://ojs.unud.ac.id/index.php/eum/article/view/55839/33010

Surya, A. M., Pertiwi, D. \& Masrul. (2018). Hubungan Protein Urine dengan Laju Filtrasi Glomerolus Pada Penderita Penyakit Ginjal Kronik Dewasa di RSUP Dr. M. Djamil Padang Tahun 2015-2017. Jurnal Kesehatan Andalas, 7(4), 469-474. doi: 10.25077/jka.v7i4.903

Yanti. (2020). Studi Fenomenologi Faktor-Faktor Yang Berhubungan Dengan Kejadian Preeklampsia. Jurnal Kebidanan, 12(1), 20-33. doi 10.35872/jurkeb.v12i01.362

Conflict of Interest Statement: The authors declare that the research was conducted in the absence of any commercial or financial relationships that could be construed as a potential conflict of interest.

Copyright (C) 2020 Santoso, Masruroh, Amalia , and Santy. This is an open-access article distributed under the terms of the Creative Commons Attribution License (CC BY). The use, dis- tribution or reproduction in other forums is permitted, provided the original author(s) and the copyright owner(s) are credited and that the original publication in this jour- nal is cited, in accordance with accepted academic practice. No use, distribution or reproduction is permitted which does not comply with these terms.

\section{UCAPAN TERIMA KASIH}

Terimakasih kepada para rekan yang membantu dalam penelitian ini 